\title{
First Record of the Exotic Red-eared Slider, Trachemys scripta elegans (Wied 1838) (Emydidae) from Assam, India
}

\author{
Jayaditya Purkayastha, Rupankar Bhattacharjee, and Sanath Chandra Bohra
}

Help Earth, Raghunath Choudhury Path, Lachitnagar, Guwahati 781007, Assam, India (mail.jayaditya@gmail.com)

G obally, turtles are represented by 353 currently rec-

ognized species (Uetz et al. 2020) and are one of the most threatened groups of vertebrates (Turtle Conservation Coalition 2018). India is home to 29 species of tortoises and freshwater turtles, $80 \%$ (23 species) of which are threatened with extinction (Purkayastha et al. 2015; Mongabay 2019). More species (20) have been recorded from Assam than any other Indian state (Purkayastha 2013; Nath et al. 2018).

Red-eared Sliders (Trachemys scripta elegans), which are native to the southeastern United States and Mexico (Ernst et al. 1994), are among the most frequently traded reptiles. Due to their small size, easy maintenance, and relatively low cost (Teillac-Deschamps et al. 2008), they have become very popular pets. However, as they grow (to $30 \mathrm{~cm}$ carapace length), they become difficult to maintain in tanks and often are released into the wild by owners totally oblivious to the effects on native ecosystems (Teillac-Deschamps et al. 2008). In India, Trachemys scripta elegans has been recorded from West Bengal (Choudhuri et al. 2018), Goa (Jadav et al. 2018), Gujarat (Vyas 2019), Maharashtra, Karnataka, Hyderabad, and Chandigarh (see Vyas 2019).

Herein we report the first records of Red-eared Sliders (Fig. 1) from Assam. During surveys on the turtles of the state, we encountered two individuals, both from Guwahati City. On 17 August 2018, we found one individual in the Deeporbeel Wildlife Sanctuary $\left(26.117694^{\circ} \mathrm{N}, 91.649353^{\circ} \mathrm{E}\right)$ and on 12 June 2019, we found another in the Ugratara Temple Pond $\left(26.189000^{\circ} \mathrm{N}, 91.754215^{\circ} \mathrm{E}\right)$.

Assam, with a human population exceeding 31 million, is the most populous state in northeastern India and is becoming increasingly developed. These factors impose an ever-increasing pressure on the biodiversity of the state, primarily due to habitat alteration and degradation. Given the present scenario, the introduction of an exotic species can rapidly exacerbate the existing problems. For example, since the Yellow-bellied Gecko (Hemidactylus flaviviridis) was introduced in Guwahati, likely arriving via the interstate

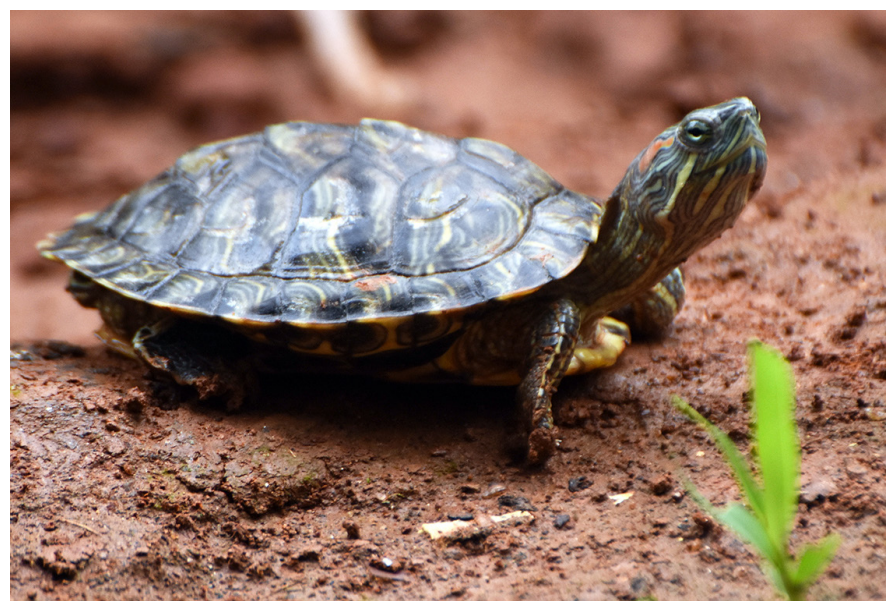

Fig. 1. A young Red-eared Slider (Trachemys scripta elegans) from the Ugratara Temple Pond at Guwahati, Assam, India. Photograph by Jayaditya Purkayastha.

transportation system, it has completely eliminated the local gecko from the habitat into which the invasive species has expanded. In India, strict laws dealing with exotic species are urgently needed for the conservation of native species.

\section{Literature Cited}

Chaudhuri, A., A. Banerjee, S. Chowdhury, and K. Deuti. 2018. Report of redeared slider turtle (Trachemys scripta elegans) from a wetland near Kolkata, West Bengal, India. The Herpetological Bulletin 146: 41-42.

Das, M., J. Purkayastha, A.M. Bauer, and S. Sengupta. 2011. Hemidactylus flaviviridis Rüppell, 1835 (Sauria: Gekkonidae) an invasive gecko in Assam. Northwestern Journal of Zoology 7: 98-104.

Ernst, C.H., J.E. Lovich, and R.B. Barbour. 1994. Turtles of the United States and Canada. Smithsonian Institution Press, Washington, D.C.

Jadhav, T.D., N.S. Sawant, and S.K. Shyama. 2018. Diversity and distribution of freshwater turtles (Reptilia: Testudines) in Goa, India. Journal of Threatened Taxa 10: 12194-12202.

Mongabay. 2019. Chance rescue turns out to be first record of elusive tortoise species in India. <https://news.mongabay.com/2019/07/chance-rescue-turnsout-to-be-first-record-of-elusive-tortoise-species-in-india/>.

Nath, A., H. Singha, and P. Deb. 2018. First report on the presence of Amyda cartilaginea (Boddaert, 1770) from Assam, India. Hamadryad 38: 39-43.

Purkayastha, J. 2013. An Amateur's Guide to the Reptiles of Assam. EBH Publisher, Guwahati, India. 
Purkayastha, J., I. Das, and S. Sengupta. 2015. Freshwater Turtles and Tortoises of South Asia. Bhabani Books, Guwaha, India.

Teillac-Deschamps, P., V. Delmas, R. Lorrillière, V. Servais, A. Cadi, and A. Prévot Julliard. 2008. Red-eared slider turtles (Trachemys scripta elegans) introduced to French urban wetlands: an integrated research and conservation program. Herpetological Conservation 3: 535-537.

Turtle Conservation Coalition (C.B. Stanford, A.G.J. Rhodin, P.P. van Dijk, B.D. Horne, T. Blanck, E.V. Goode, R. Hudson, R.A. Mittermeier, A. Currylow, C. Eisemberg, M. Frankel, A. Georges, P.M. Gibbons, J.O. Juvik, G. Kuchling, L. Luiselli, H. Shi, S. Singh, and A. Walde [eds.]). 2018.
Turtles in Trouble: The World's 25+ Most Endangered Tortoises and Freshwater Turtles. IUCN SSC Tortoise and Freshwater Turtle Specialist Group, Turtle Conservancy, Turtle Survival Alliance, Turtle Conservation Fund, Chelonian Research Foundation, Conservation International, Wildlife Conservation Society, and Global Wildlife Conservation, Ojai, California.

Uetz, P., P. Freed, and J. Hošek (eds.). 2020. The Reptile Database. <http://www. reptile-database.org>.

Vyas, R. 2019. Distribution of invasive Red-eared Sliders, Trachemys scripta (Testudines: Emydidae) in the wetlands of Gujarat State, India. Reptiles \& Amphibians 26: 145-150. 